\title{
有機フォトクロミック材料からなる機能性薄膜
}

\author{
須丸公雄 \\ 産業技術総合研究所バイオニクス研究センター \\ 干 305-8565＼cjkstart茨城県つくば市東 1-1-1 つくば中央第 5
}

\section{Functional Membranes Composed of Organic Photochromic Materials}

\section{Kimio Sumaru}

\author{
Research Center of Advanced Bionics, National Institute of Advanced Industrial Science and Technology \\ Tsukuba Central 5th, 1-1-1 Higashi, Tsukuba, Ibaraki 305-8565, Japan
}

\begin{abstract}
Past researches on the photo-functional membrane composed of organic photochromic materials are overviewed and our recent researches oriented new applied development are introduced. In our researches using original photochromic polymers, we examined the photo-control of mass transfer and living cell adhesion. In terms of a porous membrane modified with a polymer hydrogel functionalized with spiropyran, blue light irradiation enhanced its permeability for $1 \mathrm{mM} \mathrm{HCl}$ aqueous solution by more than twice and this photo-response was repeated a few times. On the other hand, in the experiment using living $\mathrm{CHO}$ cells, it was observed that the cell adhesion at the surface of a blend polymer composed of poly ( $N$-isopropylacrylamide) containing a nitrospiropyran residue enhanced remarkably by the irradiation of UV light with $365 \mathrm{~nm}$ wavelength and was reset to the former state by the subsequent visible light irradiation. Using this polymer surface, photo-induced living cell patterning with the 200 micron line width was also demonstrated.
\end{abstract}

Key words : photochromic materials / spiropyran / azobenzene / photo-response / cell adhesion

\section{1.はじめに}

有機フォトクロミック材料とは，光照射によって 化学構造が変化し，それに伴いその性質も変化する 分子材料のことであり，可逆的な変化を示すものと して, スピロピラン類, アゾベンゼン類, ジアリー ルエテン類などが知られている (Fig. 1) 1)。これら の応用に関する研究は，様々な分野で盛んに行われ， その一部は光記録媒体として既に広く実用化されて いる．膜の分野に扔いても，有機フォトクロミック 材料を用いることによって, 膜の機能に光応答性を 付与する研究がこれまで数多くなされてきた．本稿 では，有機フォトクロミック材料を用いた光機能性 薄膜に関する既往の研究及び最近の動向について概 説する.

\section{2. 光による物質移動制御}

光を用いて物質移動を制御する試みとしては, Shinkai らによって開発された光応答性キャリア膜を 第一に挙げるべきであろう ${ }^{2)}$. 彼らは，アゾベンゼン 骨格を導入することでその包接能を光で制御できる クラウンエーテルを開発，これを $\mathrm{K}^{+}$イオンのキャリ アとして液膜を構成し, イオン輸送が光でスイッチ されることを実証した ${ }^{2,3)}$.さらにアゾベンゼン修飾 クラウンエーテルを液晶分子と共に高分子多孔膜中 に分散させて複合膜を形成し, 光照射によってイオ ン透過性の完全 on/off 制御にも成功している 2,4$)$.こ こで興味深いのは, feed 側とstrip 側でそれぞれ異な る波長の光を照射することで，キャリアとイオンの 結合定数をダイナミックに変化させている点である. これによりキャリアがfeed 側でイオンを掴み, strip 側で放す動作が実現される（Fig. 2). 

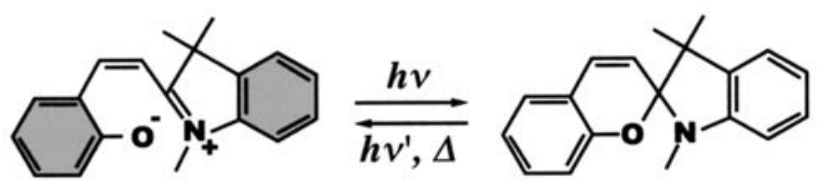

Spiropyran
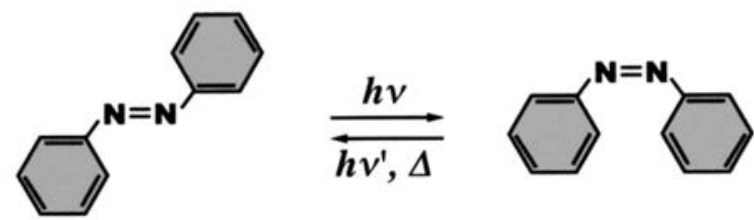

Azobenzene
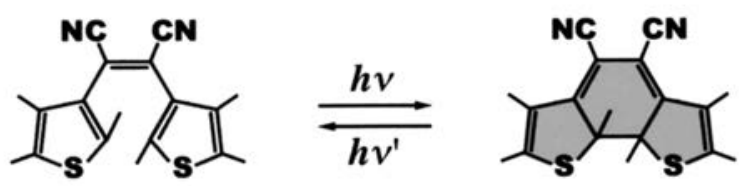

Diarylethene

Fig. 1 Isomerization of organic photochromic materials.

同じ頃にShimidzu らは，スピロピラン色素をベー スにしたイオンキャリアの液膜を用いて，イオンの 能動的輸送に成功している5).これも上述の研究同様, 光によるキャリア駆動の原理（Fig. 2）に基づくもの であるが，濃度勾配に逆らうイオンの輸送を，光の みをエネルギー源として初めて実現している。光を 単なるゲート入力としてではなく，キャリアを駆動 する手段として用いるシステムが，我が国の研究者 らによって，この時点で既に実現されていたことは 注目に值する。

光応答性のキャリアを用いた類似のイオン輸送に ついては，その後もいくつかの研究が報告されてい るが 6,7), その一方でイオン以外の物質透過の光制御 は，リポソームなどの脂質膜の系8,9) を含めてもあま り例がない. Aoyamaらは，様々な有機化合物に対し て光応答透過性を示す機能膜を，アゾベンゼンを含 むグラフトコポリマーを用いて作製，特にマンデル 酸に対する透過性が，光照射によって 5 倍以上変化す ることを報告している ${ }^{10)}$ 。また，最近筆者らは，ア ゾポリマー薄膜の He ガス透過性が光照射によって増 加することを見出しているが，その変化はわずかで， 光制御というにはほど遠い11).

\section{3. 光による表面物性制御}

物質移動の光制御に関するこうした研究が行われ る一方で，フォトクロミック材料を担持した機能性 薄膜について，表面電位や表面形状といった表面物 性を光制御する試みもいくつかなされている. Kato

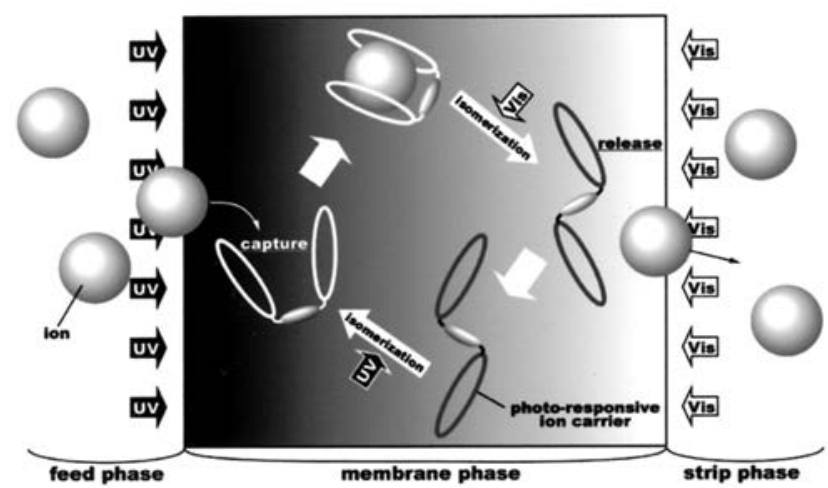

Fig. 2 Mechanism of ion transportation induced by photoresponsive binding of photochromic ion carrier.

light irradiation

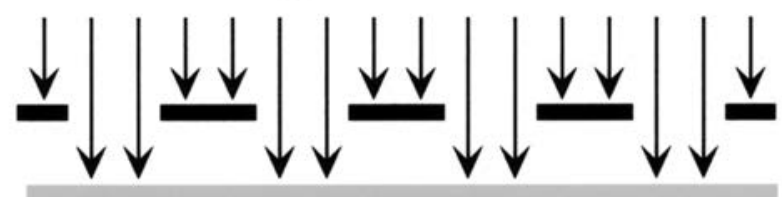

thin layer of azo-polymer

glass substrate

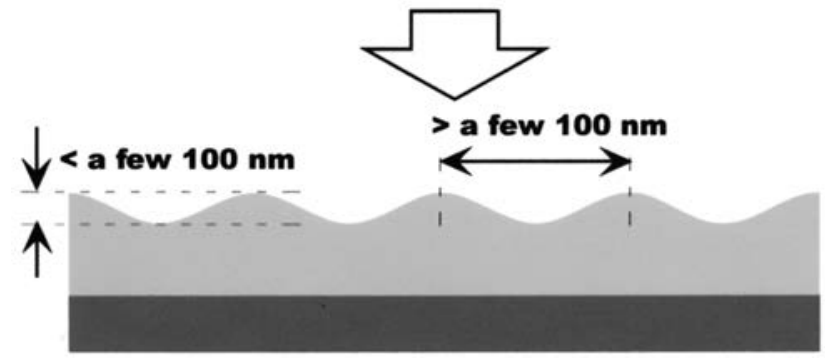

Fig. 3 Relief formation at the surface of azobenzene-containing polymer induced by inhomogeneous light irradiation.

らは，非対称な構造を有するスピロピラン含有高分 子固体膜を作製し，光照射によって膜を挟んだ等濃 度の電解質溶液の間に数 $10 \mathrm{mV}$ の電位が発生すること を報告している ${ }^{12)}$. その後Anzaiらは，対称構造を有 する膜を用いた実験系で, 光照射の方向を変えると それに対応して電位の方向も反転することを確認, 対称な系の一方の面からの光照射が, 膜の両表面に 存在するスピロピランに非対称なプロトン解離をも たらし，その結果電位が発生することを明らかにし た ${ }^{13)}$.

一方，アゾベンゼンを含むポリマー薄膜（常温で 固体）の表面形状が光照射によって変化する現象が, サブミクロンスケールで材料表面の形状を任意制御 する技術要素として注目されている．強度や偏光状 


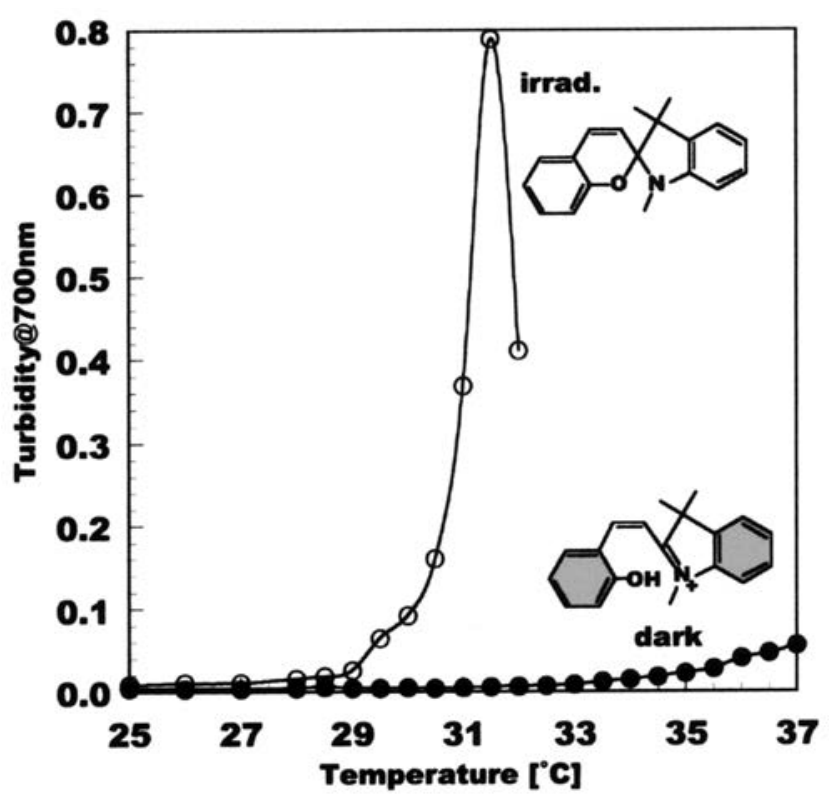

Fig. 4 Temperature-dependent turbidity at $700 \mathrm{~nm}$ of 0.1 wt $\%$ pSPNIPAAm aqueous solution containing 0.2 $\mathrm{mM} \mathrm{HCl}$ in the dark and under blue light irradiation.

態に分布を有する光を照射すると，その分布に沿っ た凹凸レリーフが薄膜表面に形成されるこの現象は (Fig. 3)，1995年に発見されて以来 ${ }^{14,15)}$ ，現在も様々 な応用に向けて盛んに研究が行われている ${ }^{16,17)}$ 。そ の形成メカニズムの全容はまだ明らかになっていな いが, 膜厚や光学密度, 光強度分布と形成されるレ リーフ形状の関係については，筆者らによって提案 された理論モデルが，多くの実験データと整合する 結果を得ている ${ }^{18,19)}$.

\section{4. スピロピランポリマーの膜システムへの 応用}

数あるフォトクロミック材料の中でも，スピロピ ラン類とアゾベンゼン類は光物性制御の手段として 用いられることが多いが，上述の通り，このことは 膜の機能化についても同様である。特にスピロピラ ン類は，光異性化によって構造とプロトン解離特性 が大きく変化するため, 光照射に応答して大きな物 性変化を示すことが期待できる。筆者らは，スピロ ピランを有機フォトクロミック分子として側鎖に有 する感温性ポリマーを数多く合成し，そのうちのい くつかが, 光照射に応答して可逆的に水和や荷電の 状態を著しく変化させることを見出した。そして， これらフォトクロミックポリマーを担持した多孔性 透過膜および細胞接着膜を作製し，水溶液に対する 透過特性や細胞接着性を光で制御する技術の開発を 進めている. 最近, これらの新規機能膜について,

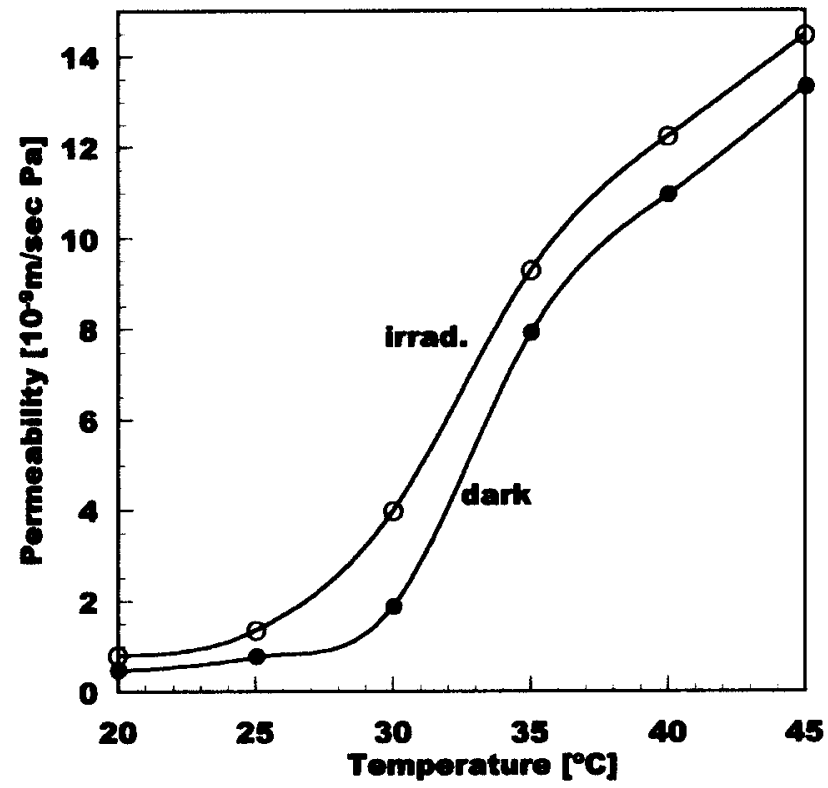

Fig. 5 Temperature-dependent permeability of pSPNIPAAm gel membrane for $1 \mathrm{mM} \mathrm{HCl}$ aqueous solution in the dark and under blue light irradiation.

いくつか興味深い知見が得られたので以下に紹介 する。

\section{1 酸性水溶液の透過制御}

感温性ポリマーとして広く知られる poly（ $N$-isopropylacrylamide）（pNIPAAm）は， $32{ }^{\circ} \mathrm{C} よ り$ 低い温 度に抒いては水に溶解する一方で, それより高温で は脱水和して析出するという独特の温度応答性を示

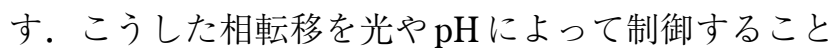
を意図して筆者らは, pNIPAAmの側鎖にスピロピラ ンを $1 \mathrm{~mol} \%$ の割合で導入したフォトクロミックポリ マーpSPNIPAAm を合成し, その溶液物性の解析を 行った ${ }^{20}$. pSPNIPAAm 酸性水溶液中の濁度（脱水 和・析出の指標）に扔ける温度・光応答性相分離特 性（濁度変化）を Fig. 4 に示す。このポリマー溶液は, 光照射の有無にかかわらず $29^{\circ} \mathrm{C}$ 以下の温度では一相 であり，暗所下においては， $29{ }^{\circ} \mathrm{C}$ を越える温度条件 においても濁度がほとんど増加せず，ポリマーの析 出は見られない。これは, 酸性溶液中暗所下で自発 的に開環・プロトン化したスピロピランが，主鎖ポ リマーの水和状態を安定化し, 熱的に誘起される脱 水和を阻害することによる。ところがこれに青色光 を照射すると，スピロピランは疎水的な構造の閉環 体に異性化し，逆に主鎖ポリマーの水和を乱す。そ のため光照射下では, $29^{\circ} \mathrm{C}$ を越える温度条件で溶液 は急速に白濁し始め， $32{ }^{\circ} \mathrm{C}$ で脱水和したポリマーが 析出沈降する.

そこで，この鋭敏な光応答脱水和特性を応用して, 


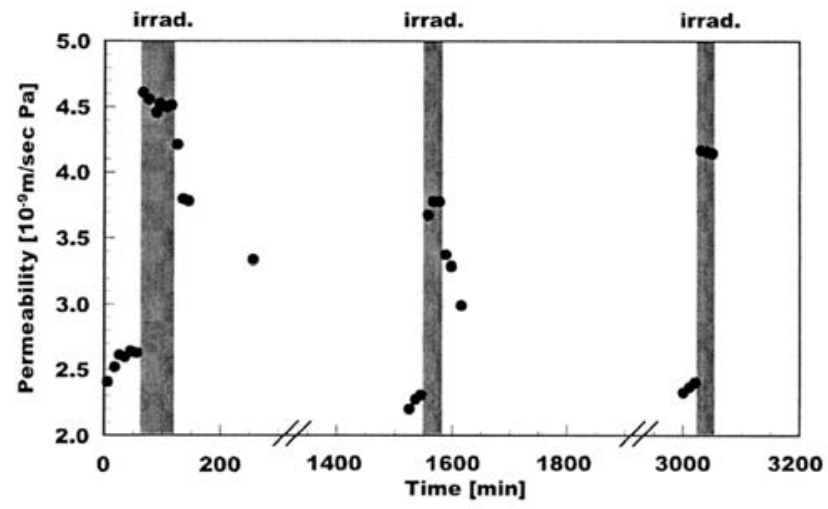

Fig. 6 Change in permeability of pSPNIPAAm gel membrane for $1 \mathrm{mM} \mathrm{HCl}$ aqueous solution in response to blue light irradiation at $30^{\circ} \mathrm{C}$.

これまでにない光物質移動制御を実現するべく, pSPNIPAAm を多孔テフロン膜（孔径 $1 \mu \mathrm{m}$ ）の表面 でゲル重合し, 光応答性膜を調製した ${ }^{21)}$. 暗所下及 び光照射下に打けるこの膜の $1 \mathrm{mM} \mathrm{HCl}$ 水溶液に対す る温度依存透過性を Fig. 5 に示す．膜の透過性は温度 の上昇と共に増加しているが，ポリマーの温度依存 相転移（脱水和 $\rightarrow$ 収縮）に対応するように，膜の透 過性が転移温度付近で特に大きく増加していること が分かる。これは，低温で膨潤し，テフロン基膜表 面の孔をふさいでいたポリマーゲルが，昇温に伴う 相転移によって収縮したことに対応すると考えられ る。また，測定したすべての温度範囲において，光 照射下の方が暗所下よりも透過性が高いという結果 が得られた。この傾向は, ポリマー水溶液系で観察 されたシャープな相転移特性 (Fig. 4) とは必ずしも 一致しないが, スピロピランの光閉環化に誘起され る脱水和の影響を反映したものと推察される.光照 射の有無による透過性の差が特に大きい $30^{\circ} \mathrm{C}$ の温度 条件で，透過性の光応答性を測定した結果を Fig. 6 に 示す．膜の透過性は光照射によって即座に 2 倍程度ま で増加し，照射下においてその状態を保持，光の遮 断後は数時間かけて元の低い透過性に戻っている. これは, ポリマーの光応答性が最も大きくなる共存 プロトン濃度条件 $(0.1-1 \mathrm{mM})$ では，色素閉環体を光 で開環化させることができないため, 異性化の戻り の過程を専ら暗所に扔ける色素の自発的な異性化に 委ねていることによる ${ }^{20,22)}$ 。こうした透過性の光制 御は繰り返し行うことが可能であり, 光によっても たらされる変化が可逆的であることが確認された。

\section{2 細胞接着性の in situ 制御}

フォトクロミックポリマーの新しい応用技術とし て筆者らは, 光の局所照射によって, 生きた細胞の
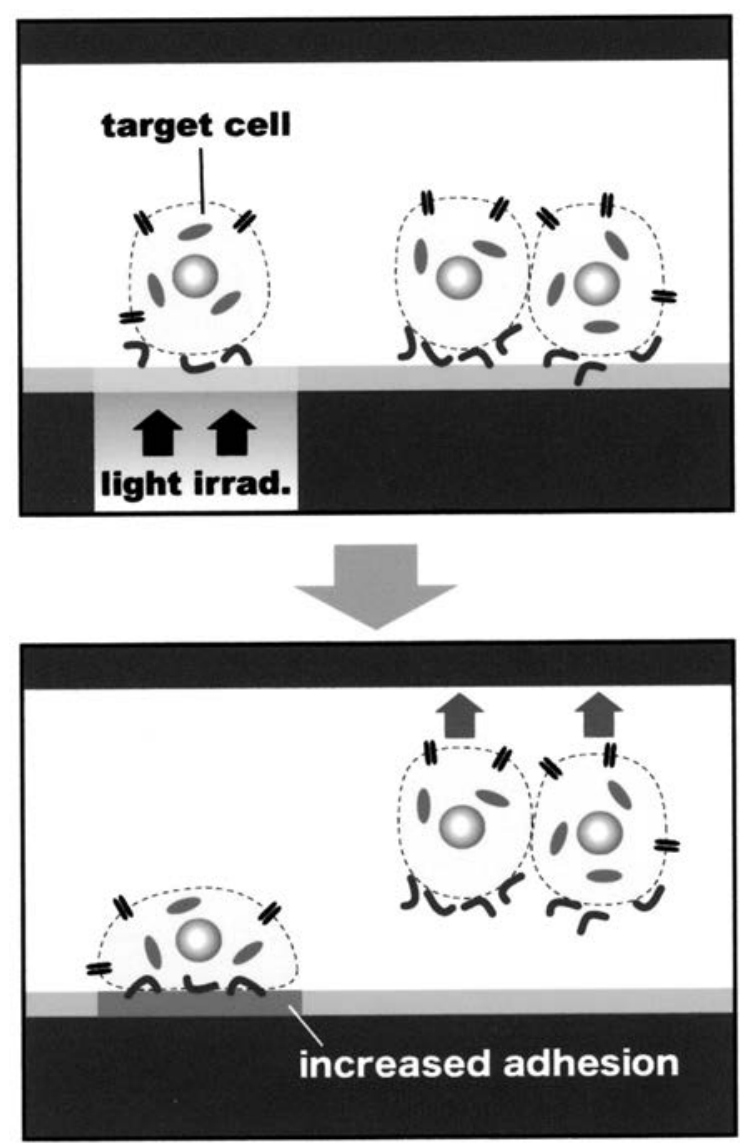

Fig. 7 In situ cell manipulation implemented with photoresponsive adhesion of photochromic polymer surface.

接着性を「その場」で制御する手法の開発を進めて いる (Fig. 7). その中で，ニトロスピロピランを含 むポリマーブレンド薄膜表面の細胞接着性が, 光で 大きく変化する条件を見出した ${ }^{23)}$. まず，二トロス ピロピランを側鎖に有する pNIPAAm と PMMAのポ リマーブレンド薄膜を, 細胞接着性の光制御を実現 する光応答性培養基材としてガラスプレート上に調 製した。そしてその表面にCHO 細胞を一様に播種し, しばらくインキュベータ内で静置した後（Fig. 8a）, 波長 $365 \mathrm{~nm}$ の紫外光を細胞越しに局所照射すると, その領域のみで細胞接着性が大きく六進, その後の 冷却・洗浄操作によって非照射領域のほとんどの細 胞が除かれるのに対して, 照射領域では多くの細胞 が残存することが確認された (Fig. $8 \mathrm{~b})$ ） フォトリン グラフィーや電子線照射などで予めパターン形成を 行う従来技術と異なり，既に存在するどの細胞の接 着と制御するかを観察に基づいて後から自由に決め られる点にご注目いただきたい。

光照射によって充進した細胞接着性は, 可視光照 射後にインキュベータ内でしばらく静置することで 再び元の状態に戻り, 同様の細胞接着操作を繰り返 
(a)

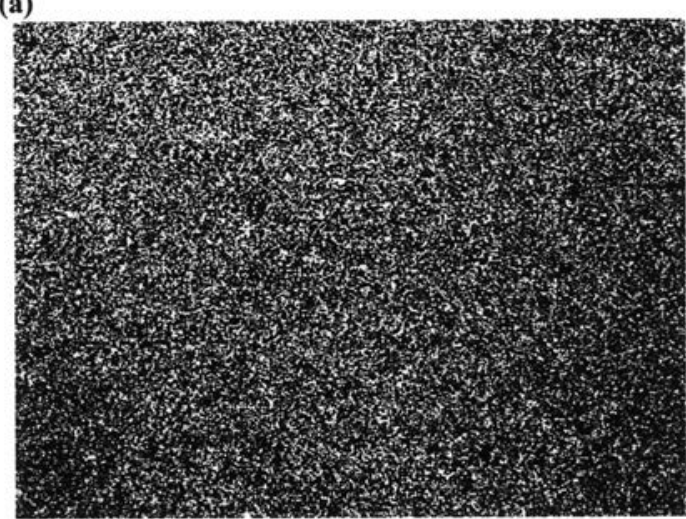

(b)

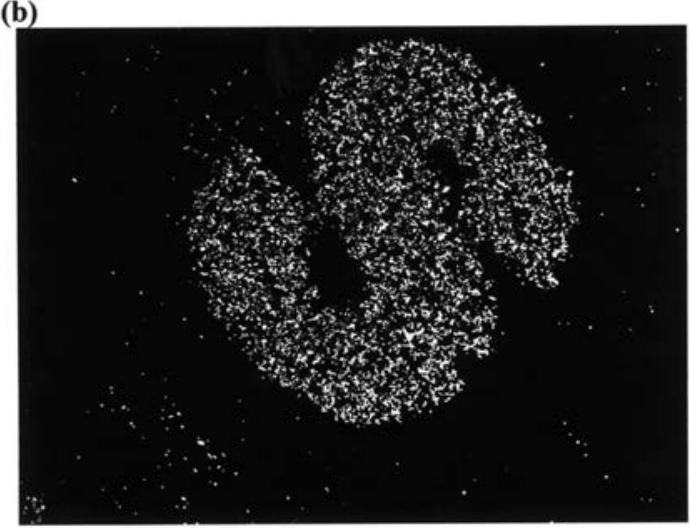

Fig. 8 Fluorescence image of living $\mathrm{CHO}$ cells on photochromic polymer surface (a) before and (b) after local light irradiation in the pattern "s" and low temperature washing.

し行うことができる。また，薄膜上での光照射・冷 却・洗浄を含む一連の操作の後も, 細胞が十分な viabilityを維持し，正常に増殖することも確認している. さらに，簡便な光学系を用いた光照射によって，線 幅 $200 \mu \mathrm{m}$ のセルパターニングの実現が実証された (Fig. 9). 以上の結果は, この光応答性薄膜と局所光 照射系によって，従来にない細胞操作が実現できる ことを示唆するものであり, 実用化に向けた研究開 発が引き続き進められている。

\section{5. おわりに}

光応答性キャリア液膜に関する最初の報告から既 に四半世紀が経過した。しかしこれまで，膜の制御 手段に関して，「どうしても光で」という場面が想定 されることはあまりなく，その結果，光応答性を有 する機能膜の応用が具体的に検討されることは，実 際のところほとんどなかった。しかし，化学反応や 細胞操作に関する研究の最近の動向において, これ らの技術シーズを取り巻く状況が，ここに来てよう やく変わりつつあると筆者は考える。昨今, 化学プ

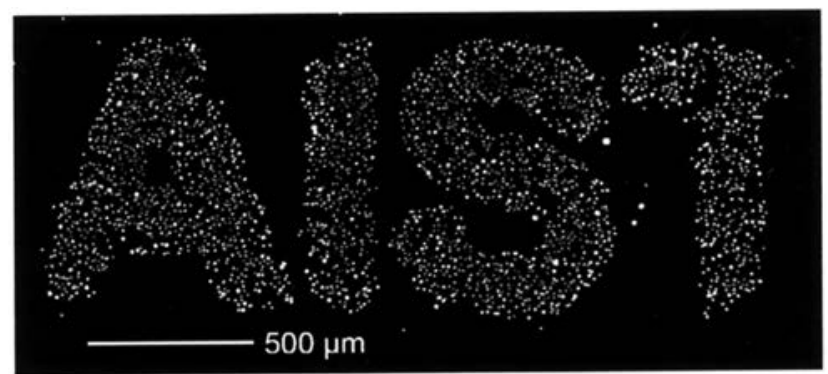

Fig. 9 Cell patterning in the pattern "AIST" with $200 \mu \mathrm{m}$ line width formed on photochromic polymer surface by light irradiation on uniformly seeded CHO cells.

ラントや分析装置をチップ上に構築し, 集積化によ ってシステムを小型化することに加え， $\mu \mathrm{m}$ スケー ルの微小な系に固有の化学プロセスの有用性を積極 的に活用する試みが，盛んになされている ${ }^{24,25)}$.ま たバイオの分野においても, 新たな細胞操作技術に 対するニーズがにわかに高まっている26). 光は対象 に対して，局所的・遠隔的・即時的にさせることが できる唯一の制御手段であり，これによって物性が 制御される膜は, 上述のマイクロ化学プロセスや細 胞の個別操作などにおいて, 多数の微小な対象（マ イクロバルブや細胞など）を独立かつ並列的に制御 する上で, 重要な要素技術となる可能性が大いにあ る. 光機能膜に関する筆者らの研究はまだ緒に就い たばかりであるが，こうした新たな応用展開を指向 する研究例として，ここで既往の研究と共に紹介さ せていただいた。この分野の今後の展開に期待し たい.

\section{謝辞}

本稿で紹介した筆者らの研究の一部は, 平成 14 年 度 NEDO 産業技術研究助成事業, および独立行政法 人日本学術振興会平成 16 年度科学研究費補助金基盤 研究（B）（No. 16360417）の助成を受け実施された ものである。

\section{文献}

1） 入江正浩：高分子, 47 449-452（1998）

2) 新海征治：化学, 41 78-84 (1986)

3) Shinkai S, Nakaji T, Ogawa T, Shigematsu K, Manabe O : J. Am. Chem. Soc., 103 111-115 (1981)

4) Kumano A, Niwa O, Kajiyama T, Takayanagi M, Kano K, Shinkai S : Chem. Lett., 1327-1330 (1983)

5) Shimidzu T, Yoshikawa M : J. Membr. Sci., 13 1-13 (1983)

6) Haberfiled P :J. Am. Chem. Soc., 109 6178-6179 (1987)

7) Winkler JD, Deshayes K, Shao B : J. Am. Chem. Soc., 111 769-770 (1989) 
8) Kano K, Tanaka Y, Ogawa T, Shimomura M, Okahata Y, Kunitake T: Chem. Lett., 421-424 (1980)

9) Sato T, Kijima M, Shiga Y, Yonezawa Y : Langmuir, 7 2330-2335 (1991)

10) Aoyama M, Watanabe J, Inoue S : J. Am. Chem. Soc., 112 5542-5545 (1990)

11) Kameda M, Sumaru K, Kanamori T, Shinbo T : J. Appl. Polym. Sci., 88 2068-2072 (2003)

12) Kato S, Aizawa M, Suzuki S : J. Membr. Sci., 2 39-47 (1977)

13) Anzai J, Sasaki H, Ueno A, Osa T : Chem. Lett., 1443-1466 (1985)

14) Rochon P, Batalla E, Natansohn A : Appl. Phys. Lett., 66 136 (1995)

15) Kim DY, Tripathy SK, Li L, Kumar J, : Appl. Phys. Lett., 66 1166 (1995)

16) Zettsu N, Fukuda T, Matsuda H, Seki, T : Appl. Phys. Lett., 834960 (2003)

17) Keum C-D, Ikawa T, Tsuchimori M, Watanabe O : Macromolecules, 364916 (2003)

18) Sumaru K, Yamanaka T, Fukuda T, Matsuda M : Appl. Phys. Lett., 75 1878-1880 (1999)

19) Sumaru K, Fukuda T, Kimura T, Matsuda H, Yamanaka T: J. Appl. Phys., 91 3421-3430 (2002)

20) Sumaru K, Kameda M, Kanamori T,Shinbo T : Macromolecules, 37 4949-4955 (2004)

21）大井克秀, 須丸公雄, Samuel P. Kusumocahyo, 高木 俊之，金森敏幸：第 53 回高分子討論会予稿集, p.5017
(2004)

22) Sumaru K, Kameda M, Kanamori T,Shinbo T : Macromolecules, 37 7854-7856 (2004)

23) Edahiro J, Sumaru K, Tada Y, Ohi K, Takagi T, Kameda M, Shinbo T, Kanamori T, Yoshimi Y : Biomacromolecules, 6 970-974 (2005)

24）北森武彦, 庄子習一, 馬場延信, 藤田博之：「マイクロ化 学チップの技術と応用」, 丸善 (2004)

25) Thorsen T, Maerkl SJ, Quake SR : Science, 298580 (2002)

26）岡野栄之, 阿形清和：細胞工学, 19 368-373（2000）など

(Received 15 March 2005;

Accepted 7 April 2005)

\section{著者略歴}

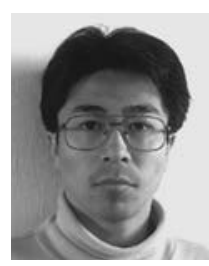

須丸 公雄 (すまる きみお)

1991年3月 京都大学工学部高分子化 学科卒業

1995年 4 月 日本学術振興会特別研 究員

1996年 3 月 京都大学大学院工学研究 科博士後期課程修了

1996年 4 月 通商産業省工業技術院物質工学工業技術研究 所入所

2001 年 4 月 組織改編により, 独立行政法人産業技術総合 研究所主任研究員 